\title{
Processes Generating Convection Cells near Sumatra Island in the Monsoon Season
}

\author{
by \\ Hiromu Seko, Syugo Hayashi, and Kazuo Saito \\ Forecast Research Department, Meteorological Research Institute, Tsukuba, Japan
}

(Received February 23, 2012; Accepted August 6, 2012; Published December 19, 2012)

\begin{abstract}
We investigated processes generating convection cells in tropical regions using a high-resolution, 3-dimensional, non-hydrostatic model. Convection cells near Sumatra Island were reproduced by using reanalysis data of the Japan Meteorological Agency Climate Data Assimilation System. Downscaled experiments with a horizontal grid interval of $1 \mathrm{~km}$ showed that convection cells were generated by the passage of updrafts of low-level waves over an area of largescale convergence or over the leading edge of a weak cold pool. The large-scale convergence gradually decreased the temperature and increased the relative humidity of the atmosphere below a height of $2 \mathrm{~km}$. The atmosphere above the leading edge of the weak cold pool was almost saturated. These atmospheric conditions were favorable for the generation of convection. The updrafts of low-level waves also decreased the temperature and increased the relative humidity in the updraft regions. These changes caused by the low-level waves triggered new convection cells. The low-level waves had the structure of gravity waves, as shown by the temporal lag of about $90^{\circ}$, of temperature minimums behind the updraft maximums. The changes in the lower atmosphere caused by the large-scale convergence created conditions that allowed convection cells to be generated easily, but the intensity of the low-level waves determined the timing of the generation.
\end{abstract}

\section{Introduction}

Understanding the evolution of convection cells is important for both accurate prediction of meteorological disasters and climate research. Several studies have addressed the role of gravity waves (GWs) in the generation of convection cells in tropical regions. For instance, Yamasaki and Seko (1992) (YS92) simulated convection cells with a high-resolution 2-dimensional non-hydrostatic model to investigate their generation mechanisms in tropical regions. According to YS92, GWs generated convection cells by increasing moisture and decreasing temperatures in updraft regions when updrafts of GWs coming from opposite directions overlapped or when GWs propagated into a humid region. Furthermore, Oouchi (1999) performed idealized experiments using a two-dimensional model with a horizontal grid interval of 1 $\mathrm{km}$ and showed that GWs contributed to the formation of tropical superclusters. However, in the results of YS92 and Oouchi (1999) the effect of GWs was likely exaggerated because representation of the horizontal propagation of GWs

Corresponding address:

Meteorological Research Institute,

1-1 Nagamine, Tsukuba, Ibaraki 305-0052, Japan.

E-mail: hseko@mri-jma.go.jp was limited by their 2-dimensional models.

Lac et al. (2002) used 3-dimensional numerical models with a horizontal grid interval of $5 \mathrm{~km}$ to investigate the role of GWs in the development of convective systems. They reproduced mesoscale convective systems observed in the Tropical Ocean Global Atmosphere Coupled Ocean-Atmospheric Response Experiment. They found that ascending phases of GWs favor moistening and cooling and that convection cells are triggered when the ascent phases of shallow- and deepmode GWs combine. Recently, the horizontal grid interval of numerical models used for investigating the role of GWs has become as short as a few kilometers, because high resolution is essential for proper representation of convection cells. For instance, Lane and Zhang (2011) investigated the relationship between a tropical cloud population and mesoscale GWs by using an idealized cloud-resolving model with a grid interval of $1 \mathrm{~km}$. They found that the spacing of cloud systems was determined by the characteristic convection timescale. Wang et al. (2011) demonstrated that observed GWs could trigger the development of new convection cells in the Taiwan Strait by using the Cloud-Resolving Storm Simulator model with a $2 \mathrm{~km}$ grid interval to reproduce a heavy rainfall event. However, relatively few studies have used fine-resolution, 3-dimensional models to examine the role of GWs in the 
generation of convection cells. In particular, the processes by which GWs generate convection cells have not been fully investigated. To improve our understanding of the role GWs play in the generation and development of convection cells, numerical experiments must be conducted with highresolution models and high-quality analysis data in order to reproduce atmospheric phenomena more realistically.

In this study, we focused on the primitive mechanisms of the generation and development of individual convection cells by using a high-resolution 3-dimensional model with a grid interval of $1 \mathrm{~km}$ in which convection cells observed near Sumatra Island on 28-29 January 2008 were reproduced. To reproduce the evolution of convection cells more realistically, including their relationship with GWs, we conducted our experiments by using realistic initial fields obtained from the Japan Meteorological Agency Climate Data Assimilation System (JCDAS) (Onogi et al., 2007). In section 2, we describe the result obtained by YS92, who used a 2-dimensional model to investigate the relationship between convection cells and GWs in an idealized system. We describe the design of our 3-dimensional numerical experiments in section 3, and in section 4 we examine the relationship between convection cells and GWs in our simulation results. We summarize the processes that generate convection cells in section 5 .

\section{Idealized experiment with a 2-dimensional model}

YS92 used a 2-dimensional anelastic forecast model (Yamasaki, 1984) with a horizontal grid interval of $500 \mathrm{~m}$. The vertical profiles of temperature and humidity used as the basic fields were typical profiles for tropical regions (see Table 1 in Yamasaki, 1983). The vertical profile of the basic horizontal wind field had a vertical shear of $2 \times 10^{-3} \mathrm{~s}^{-1}$ below $3 \mathrm{~km}$ height. The horizontal domain size was set as large as $5000 \mathrm{~km}$. To produce the initial disturbances, two sets of four thermal bubbles were placed near the center of the model domain. When the numerical integration was conducted, the cold outflows and GWs produced by the initial bubbles triggered the development of successive convection cells.

Figure 1 shows Hovmöller diagrams of updrafts at 1.2 $\mathrm{km}$ height and of temperature deviations from the horizontal average at $150 \mathrm{~m}$ height. Updrafts of GWs are generated among groups of convection cells and propagate in opposite directions at speeds of 16-17 $\mathrm{m} \mathrm{s}^{-1}$ (Fig. 1a). Where the updrafts propagated from convection cells $\mathbf{A}$ and $\mathbf{D}$ meet, approximately midway between the convection cells, a new convection cell $\mathbf{F}$ is generated. Then GWs propagated from convection cells $\mathbf{B}$ and $\mathbf{E}$ intensify convection cell $\mathbf{F}$. Convection cell $\mathbf{J}$ is generated when GWs arrive from convection cell $\mathbf{G}$, and it is intensified by the arrival of GWs propagated from convection cell $\mathbf{H}$.

YS92 investigated the mechanisms that generate and intensify convection cells by examining the vertical distribution of temperature deviations from their horizontal averages.
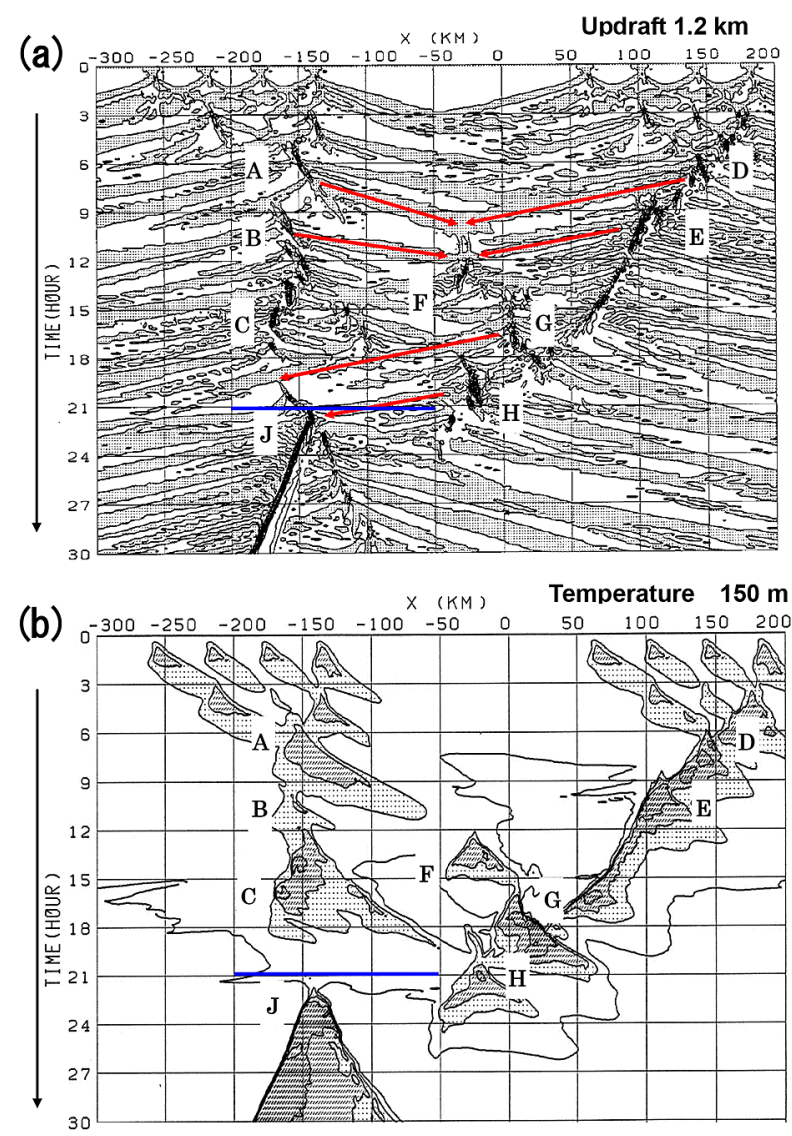

Fig. 1 Hovmöller diagrams of (a) updrafts at $1.2 \mathrm{~km}$ height and (b) temperature deviations from the horizontal average at $150 \mathrm{~m}$. Shaded regions in (a) show the updraft distribution; uppercase letters $\mathbf{A}-\mathbf{H}$ and $\mathbf{J}$ are convection cells, and red arrows show the direction of propagation of the gravity waves that generate or develop convection cells $\mathbf{F}$ and $\mathbf{J}$. Contours and shading (from light to dark) in (b) indicate regions colder than $1^{\circ} \mathrm{C}, 0^{\circ} \mathrm{C},-1^{\circ} \mathrm{C}$, and $-2^{\circ} \mathrm{C}$, respectively. The thick blue line ( $\mathrm{a}$ and $\mathrm{b}$ ) indicates the position of the vertical section shown in Fig. 2. (after Yamasaki and Seko, 1992)

Figure 2 shows the relationships among updrafts, temperature deviations, and relative humidity at 2130 UTC, when GWs propagated from convection cell $\mathbf{H}$ arrived at convection cell $\mathbf{J}$. In the updraft region at 3-6 $\mathrm{km}$ height around $\mathrm{X}=$ $-150 \mathrm{~km}$, the temperature is decreased. In addition, the thickness of the humid layer (relative humidity in excess of $80 \%$ ) increases to $4 \mathrm{~km}$ in the updraft region, compared with $2 \mathrm{~km}$ elsewhere. This time point, $2130 \mathrm{UTC}$, is just before the development of convection cell $\mathbf{J}$ (Fig. 1a), when it was located in the updraft region of the GWs and cold and humid regions were approaching. The updrafts and the cold humid air moving in behind the updrafts, which were caused by the GWs, created conditions favorable for the generation and development of new convection cells. These vertical distributions are similar to the structure of GWs in the slower moving mode of the model proposed by Nicholls et al. (1991), in which updrafts of GWs are present in the lower half of the troposphere.

Cold pools can generate new convection cells by causing 


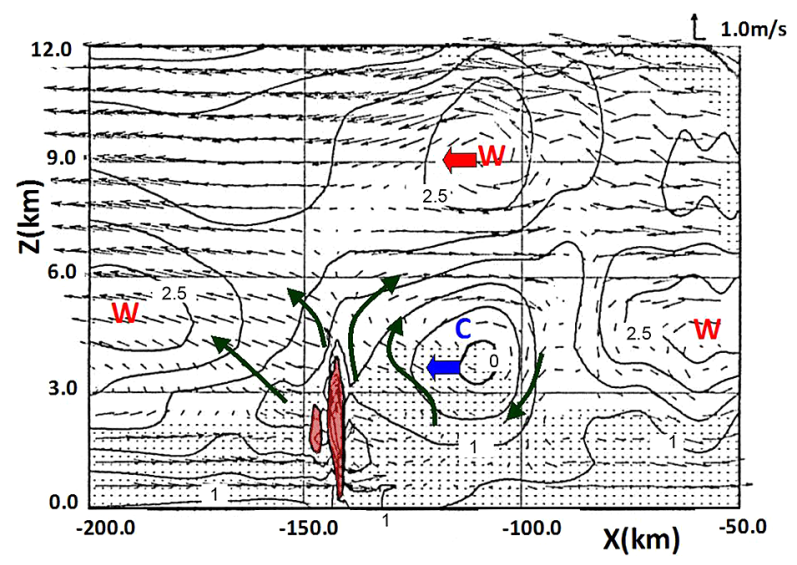

Fig. 2 Vertical section showing temperature deviations from the horizontal average (contours; contour interval, $0.5^{\circ} \mathrm{C}$ ), horizontal winds and updrafts (vectors; scale is at the upper right corner), relative humidity of more than $80 \%$ (dotted area), and clouds (red shaded areas) at 2130 UTC. The thick green arrows show airflows around convection cell $\mathbf{J}$. Red $\mathrm{W}$ and blue $\mathrm{C}$ indicate the positions of the warm and cold regions, respectively (after Yamasaki and Seko, 1992).

low-level air to be uplifted, and intense cold pools produced by convection cells are present at $150 \mathrm{~m}$ (Fig. 1b, shaded regions). Before convection cells $\mathbf{F}$ and $\mathbf{J}$ were generated, however, no intense cold pools existed at their locations (Fig. 1b). Therefore, GWs triggered and intensified the convection cells. Note, however, that these results might overestimate the effects of GWs because this 2-dimensional model is limited in its ability to represent the horizontal propagation of GWs (see section 1).

\section{Design of experiments}

To confirm the relationships between convection cells and GWs suggested by YS92, we conducted simulations with a 3-dimensional numerical model using realistic initial fields. In this study, we applied the Japan Meteorological Agency (JMA) non-hydrostatic model (NHM; Saito et al., 2006), which is the operational regional mesoscale model used at JMA, to a tropical region. To express individual convection cells, we adopted three one-way nested domains. The outer model (20km-NHM), second model (5km-NHM), and innermost model ( $1 \mathrm{~km}-\mathrm{NHM})$ had horizontal grid intervals of 20 , 5 , and $1 \mathrm{~km}$, respectively, and their domains were $2280 \mathrm{~km} \times$ $2040 \mathrm{~km}, 2170 \mathrm{~km} \times 1850 \mathrm{~km}$, and $450 \mathrm{~km} \times 450 \mathrm{~km}$ in size, respectively. In each model, the number of vertical layers was 50, and the layer thickness increased with height from $40 \mathrm{~m}$ for the lowest layer to $1.2 \mathrm{~km}$ at the model top, which was at $23.21 \mathrm{~km}$. The $20 \mathrm{~km}-\mathrm{NHM}$ and $5 \mathrm{~km}-\mathrm{NHM}$ used the Kain-Fritsch convection parameterization scheme (Kain and Fritsch, 1993). The $1 \mathrm{~km}-\mathrm{NHM}$ used a bulk method in which the mixing ratios of water substances (cloud water, rainwater, cloud ice, snow, graupel, and cloud ice) and the number density of cloud ice are based on cloud microphysical processes.
To reproduce the evolution of convection cells more realistically, JCDAS data, the global reanalysis data set produced by JMA (Onogi et al., 2007), were used for initial and boundary conditions in the $20 \mathrm{~km}-\mathrm{NHM}$. Artificial thermal bubbles were not used in the initial fields. The initial time of the $20 \mathrm{~km}-\mathrm{NHM}$ was 1200 UTC 28 January 2008, during the Southeast Asian monsoon season. The six-hour forecast of the 20km-NHM was used for the initial conditions of the $5 \mathrm{~km}-\mathrm{NHM}$, and the 21-hour forecast of the $5 \mathrm{~km}-\mathrm{NHM}$ was used for the initial conditions of the $1 \mathrm{~km}-\mathrm{NHM}$. This spinup time of 6 hours was long enough because convection cells were generated during the first 6 hours from the initial times in both the $20 \mathrm{~km}-\mathrm{NHM}$ and $5 \mathrm{~km}-\mathrm{NHM}$. The difference between the initial times of the $5 \mathrm{~km}-\mathrm{NHM}$ and the $1 \mathrm{~km}-\mathrm{NHM}$ (21 hours) was determined not by the spin-up time but by the generation time of the targeted convection cells.

\section{Generation of convection cells by gravity waves}

A satellite-derived cloud image obtained at 2100 UTC 29 January 2008 shows intense convection cloud development south of Borneo Island in the Java Sea, but relatively fewer clouds east or west of Borneo (Fig. 3a). The 1-hour rainfall and surface horizontal wind distributions reproduced by the $5 \mathrm{~km}-\mathrm{NHM}$ (Fig. $3 \mathrm{~b}$ ) show that many convection cells have been generated in the southern Java Sea. In addition, a northwesterly airflow (I) and westerly airflow (II) converge near a rainfall region east of Sumatra Island. The northwesterly airflow (I) is the trans-equatorial monsoon flow, which can cause heavy rainfalls on Java Island (Wu et al., 2007). The westerly flow (II) that converged with airflow (I) blew along the northern side of Java Island. The horizontal wind deviations from the temporal average during 0900 UTC 29 January to 0900 UTC 30 January at $520 \mathrm{~m}$ height show offshore winds along the northern side of Java Island (black ellipse in Fig. 3c). Thus, we deduced that flow (II) is produced by the weakening of the northerly component of northwesterly flow (I) by land and sea breeze circulation, which can propagate over a long distance (Moteki et al., 2008).

An intense rainfall band extending from northwest to southeast in the region east of Sumatra Island (Figs. $3 \mathrm{~d}$ and 3e) was produced by the convergence of the northwesterly (I) and westerly (III) airflow from convection cells that developed over Sumatra Island from 1500 UTC to 1900 UTC. Generation of convection cells that was produced by convergence of cold outflows from previous rainfalls generated over land region was also reported by Fujita et al.. (2009). At 1920 UTC, there were small convection cells A east of this rainfall band along the convergence line of the northwesterly (I) and westerly (II) airflows (Fig. 3d), not on the line of convergence between northwesterly airflow (I) and westerly airflow (III). Thus, they were not generated by westerly airflow from Sumatra Island (III). At 2010 UTC, small convection cells B were generated at the leading edge of a cold pool associated 
(a)

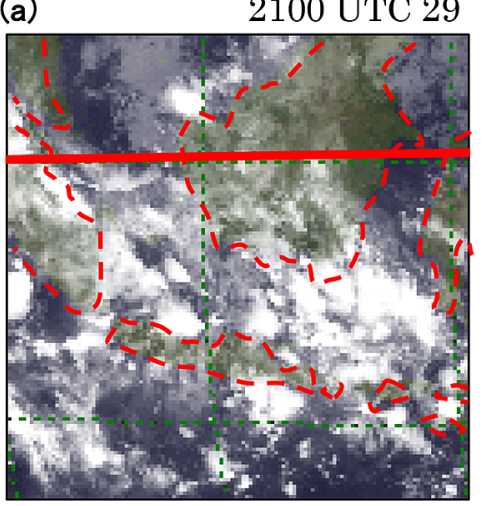

(d)

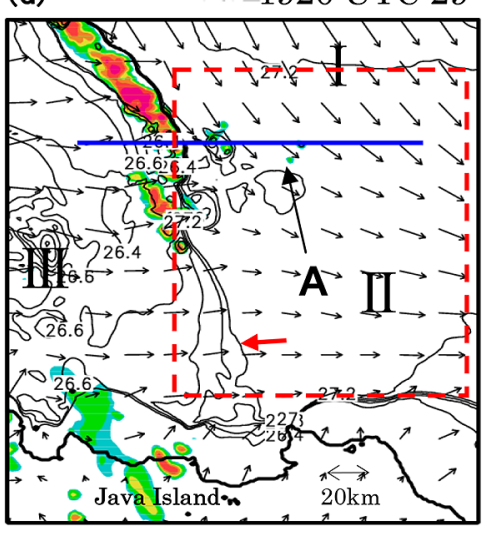

(b)

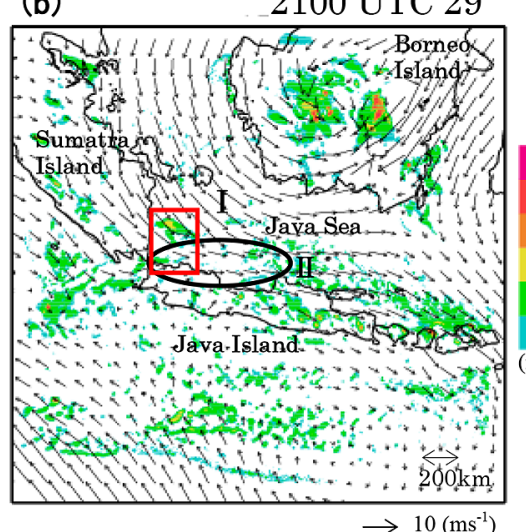

(e)

2010 UTC 29

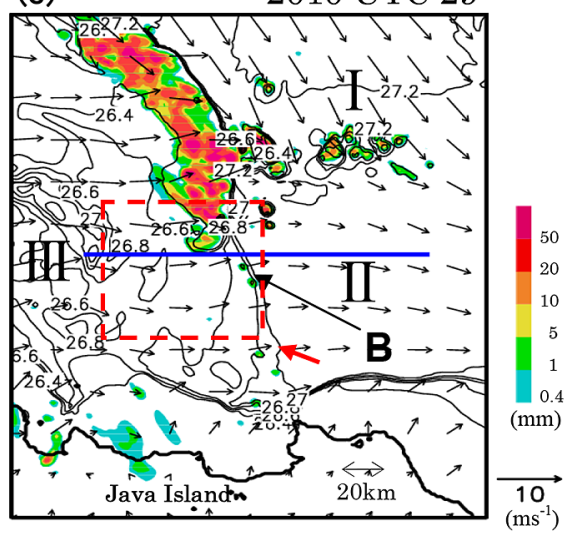

(c)

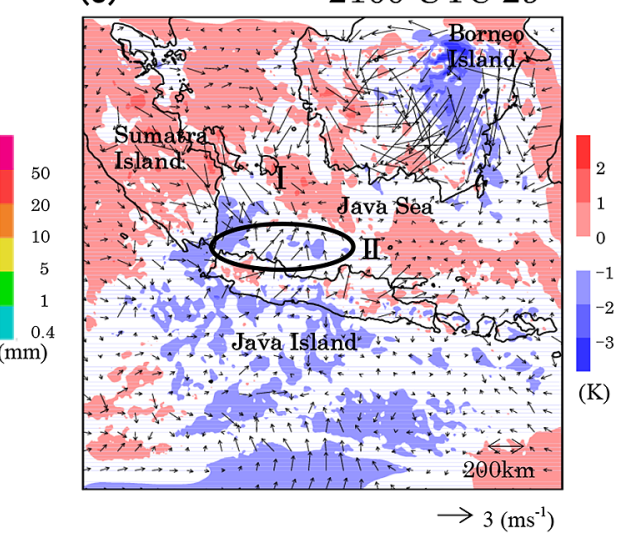

Fig. 3 (a) Infrared image observed by a geostationary meteorological satellite at 2100 UTC on 29 January 2008. The red broken lines and the red solid line indicate coastlines and the equator line, respectively. (b) Horizontal winds (vectors) at $\mathrm{z}=520 \mathrm{~m}$ and 1 -hour rainfall at 2100 UTC on 29 January reproduced by the $5 \mathrm{~km}-\mathrm{NHM}$. Initial time of the 5km-NHM simulation was 1800 UTC on 28 January. The red rectangle indicates the regions shown in (d) and (e). (c) Deviations of horizontal wind at 2100 UTC on 29 January $(z=520$ $\mathrm{m}$ ) from the temporal average during 0900 UTC on 29 January to 0900 UTC on 30 January and deviations of potential temperature at 2100 UTC on 29 January $(\mathrm{z}=1460 \mathrm{~m})$ from the 0900 UTC temperature on 29 January. (d, e) Rainfall reproduced by the $1 \mathrm{~km}-$ NHM at (d) 1920 UTC and (e) 2010 UTC on 29 January. Initial time of the $1 \mathrm{~km}-\mathrm{NHM}$ was 1500 UTC on 29 January. Contours in (d) and (e) indicate the surface temperature. Contour interval is $0.2^{\circ} \mathrm{C}$. Contours of $27.2^{\circ} \mathrm{C}$ south of the convection band are indicated by red arrows. Red broken line rectangle in (d) is the region shown Figs. 7c and d, and that in (e) is the region shown in Figs. 10c and d. Blue lines in (d) and (e) indicate the positions of the Hovmöller diagrams shown in Figs. 4 and 7 and Figs. 9 and 10, respectively.

with westerly flow (III), south of the intense rainfall band (Fig. 3e). There is no cold pool near convection cells $\mathbf{A}$, and the drop in temperature caused by the cold pool near the generation point of convection cells $\mathbf{B}$ is only about $0.2-0.4^{\circ} \mathrm{C}$. Thus, we selected these two groups of convection cells as the targets of this study because neither group was generated by an intense cold pool.

\subsection{Convection cells A, generated along the large- scale convergence line}

Convection cells $\mathbf{A}$, generated east of Sumatra Island where the northwesterly (I) and westerly (II) airflows converged (see section 4, Fig. 3d), are shown by intense updrafts of more than $1 \mathrm{~m} \mathrm{~s}^{-1}$ at $1460 \mathrm{~m}$ height (white contours in Figs. 4a and 4c). These convection cells were generated after a region of weak updrafts $\left(0.03-0.06 \mathrm{~m} \mathrm{~s}^{-1}\right)$ propagated from the west at $230 \mathrm{~m}$ height (Figure $4 \mathrm{~b}$, thin arrows). We deduced that this weak updraft region, which is $20-40 \mathrm{~km}$ wide, was produced by the convergence of the northwesterly (I) and westerly (II) airflows.
This large-scale convergence from the west caused temperatures to decrease and the relative humidity to increase at $1460 \mathrm{~m}$ height (Figs. 4a and 4c). Moreover, below $850 \mathrm{hPa}$, the dew-point temperature approached the air temperature from 1600 UTC to 1900 UTC in the area where convection cells $\mathbf{A}$ were generated, though the air temperature also decreased by $1^{\circ} \mathrm{C}$ during this period (Fig. 5). In addition, the atmosphere at around $900 \mathrm{hPa}$ became almost saturated, which reduced the convective inhibition from $30.3 \mathrm{~J} \mathrm{~kg}^{-1}$ (1600 UTC) to $0.4 \mathrm{~J} \mathrm{~kg}^{-1}$ (1900 UTC).

Several updraft regions with widths of $10-20 \mathrm{~km}$ also propagated from the east at about $11 \mathrm{~m} \mathrm{~s}^{-1}$ (broken and solid line arrows in Fig. 4a and 4c). These updrafts of low-level waves originated from convection cells in the Java Sea and were propagated westward (Fig. 6). By 0700 UTC, they were organized into a band (Fig. 6b), and they became larger as they approached Sumatra Island (Fig. 6b-e). A zonal-time diagram of the updrafts (Fig. 6f) also shows that they were propagated from the east, though because of the long interval between outputs of the $5 \mathrm{~km}-\mathrm{NHM}$ ( 1 hour), the view of their 

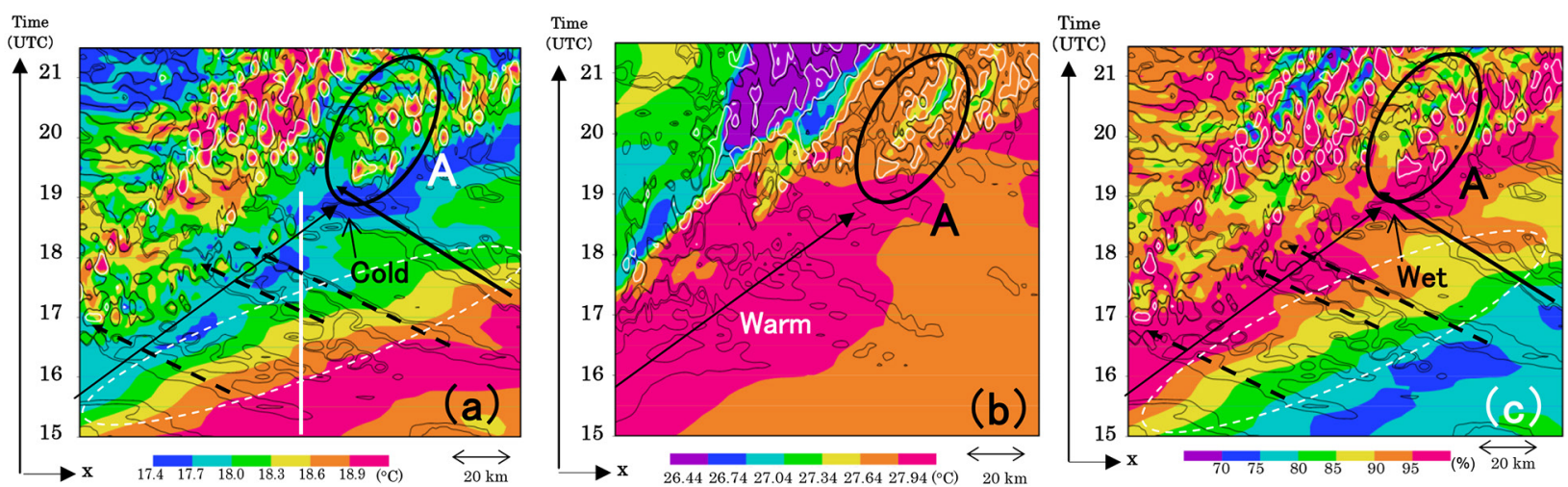

Fig. 4 Zonal-time diagrams of temperature at (a) $\mathrm{z}=1460 \mathrm{~m}$ and (b) $\mathrm{z}=20 \mathrm{~m}$ and of (c) relative humidity at $\mathrm{z}=1460 \mathrm{~m}$ along the blue line shown in Fig. 3d (color scales). Contours indicate updrafts at (a) $\mathrm{z}=1460 \mathrm{~m}$, (b) $\mathrm{z}=230 \mathrm{~m}$, and (c) $\mathrm{z}=1460 \mathrm{~m}$. Black contour lines depict updrafts with intensities of $0.03 \mathrm{~m} \mathrm{~s}^{-1}$ and $0.06 \mathrm{~m} \mathrm{~s}^{-1}$. White contour lines in (a), (b), and (c) depict updrafts with intensities of $1 \mathrm{~m} \mathrm{~s}^{-1}, 0.2 \mathrm{~m} \mathrm{~s}^{-1}$, and $1 \mathrm{~m} \mathrm{~s}^{-1}$, respectively. The solid and broken line arrows pointing west in (a) and (c) indicate updraft regions of low-level waves propagating from the east. Those updraft regions that generated convection cells $\mathbf{A}$ are indicated by the solid arrows. The arrow pointing east in each panel indicates the propagation of the updraft region produced by the large-scale convergence. The black ellipse in each panel indicates convection cells $\mathbf{A}$, and the white broken line ellipse in (a) and (c) indicates changes in temperature and humidity due to the low-level waves (see section 4.1). The solid white line in (a) indicates the longitude and time span of the height-time diagram shown in Fig. 8a.

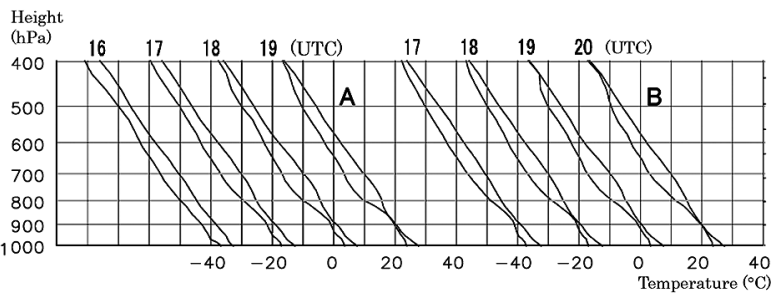

Fig. 5 Vertical profiles of air temperature and dew point temperature from 1600 UTC to 1900 UTC at the generation point of convection cells A (left) and from 1700 UTC to $2000 \mathrm{UTC}$ at the generation point of convection cells B (right). The profiles are depicted by shifting the temperatures by $-20^{\circ} \mathrm{C}$ each hour before 1900 UTC or 2000 UTC. propagation in Fig. $6 f$ is fragmented. We deduced that the increase in size of the updrafts was influenced by modification of the atmosphere caused by the land and sea breeze circulation of Java Island. The mechanisms leading to the organization of low-level waves need to be investigated in the future.

The propagation speed of the cold and moist region from the west fluctuated because of these updrafts (white dashed ellipse in Figs. 4a and 4c); the temperature decreased and the relative humidity rapidly increased when the updrafts passed from the east. These distributions were produced by adding the small changes in temperature and relative humidity

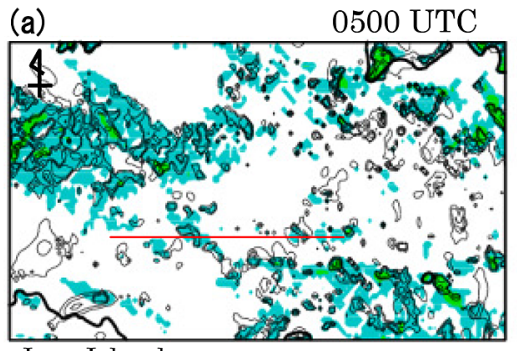

Java Island

(d)

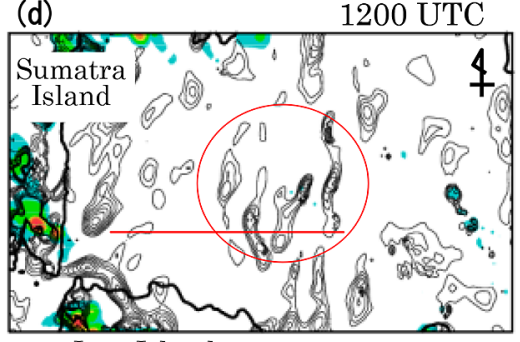

Java Island

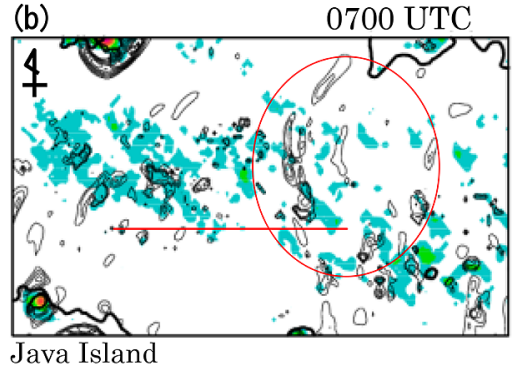

(e)

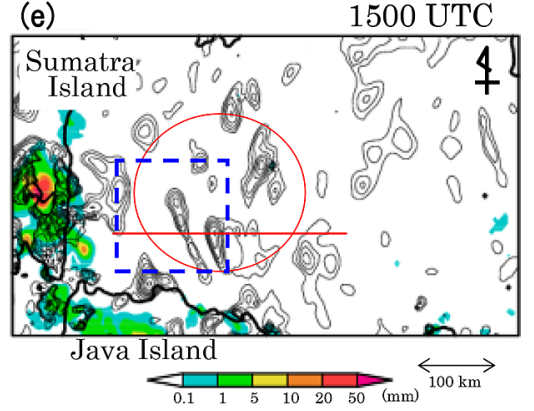

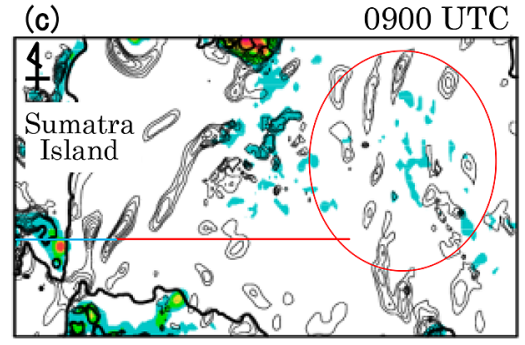

Java Island

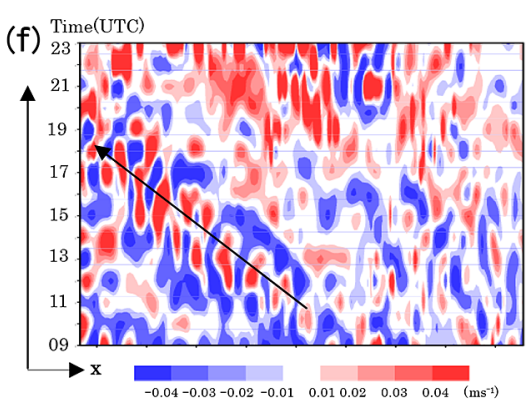

Fig. 6 (a)-(e) Horizontal distributions of updrafts at $\mathrm{z}=1460 \mathrm{~m}$ and the 1-hour rainfall between 0500 UTC and 1500 UTC on 29 January 2008 reproduced by the $5 \mathrm{~km}-\mathrm{NHM}$. Contours (contour interval, $0.02 \mathrm{~m} \mathrm{~s}^{-1}$ ) show regions in which updraft intensities are from 0.01 $\mathrm{m} \mathrm{s}^{-1}$ to $0.21 \mathrm{~m} \mathrm{~s}^{-1}$. The area depicted in panels (c) to (e) (0900 UTC to 1500 UTC) is shifted west of that depicted in (a) and (b). Red circles surround updraft regions propagating to east of Sumatra Island. The blue broken line rectangle in (e) indicates the region shown in Figs. 7c and 7d. (f) Zonal-time diagram of the updraft at $\mathrm{z}=1460 \mathrm{~m}$ from 0900 to 2300 UTC along the red line in (a)-(e). The black arrow indicates the direction of propagation of low-level updrafts. 
caused by the low-level waves to the large changes caused by the large scale convergence (Fig. 5a). To depict the relationships between the updrafts and temperature more clearly, we show increases in temperature and relative humidity during the last 10 minutes in Figs. 7a and 7b. The temperature decreases and relative humidity increases were more distinct when the updrafts of low-level waves encountered the regions of decreasing temperature and of increasing humidity caused by the large-scale convergence. The distributions of the updrafts and of the temperature deviations (Figs. 7c and 7d) show that the updraft phase coincides with decreases in temperature. This is the same relationship between updrafts and temperature as that shown by the 2-dimensional experiment of YS92 (Fig. 2).

Convection cells A (black ellipses in Fig. 4) were generated far from other convection cells at 1910 UTC, when the updrafts at $1460 \mathrm{~m}$ that had propagated from the east (solid arrows in Figs. 4a and 4c) moved above other updrafts at $230 \mathrm{~m}$ (Fig. 4b). At the point where convection cells A were generated, the temperature was decreased and relative humidity was increased by the arrival of the updrafts from
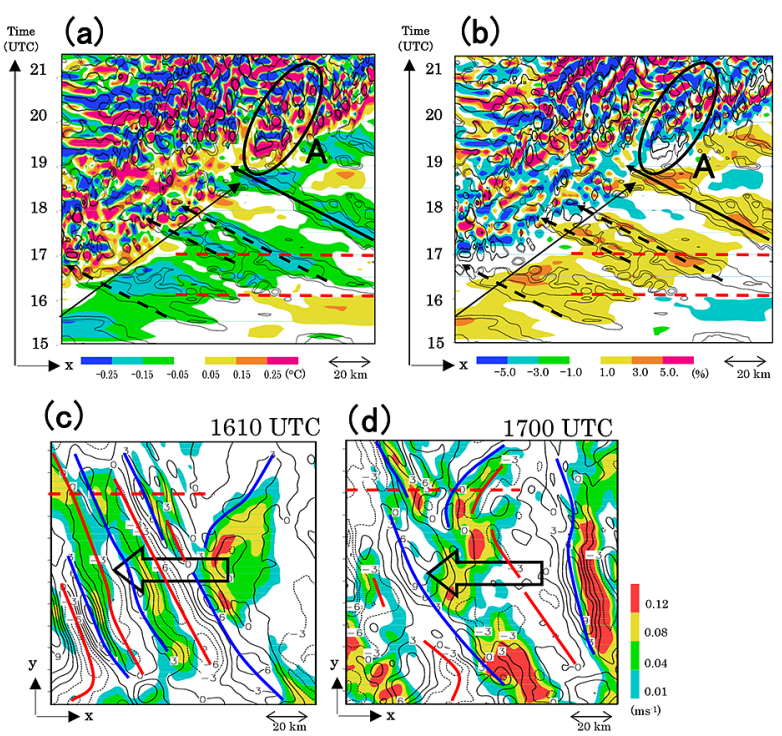

Fig. 7 Zonal-time diagrams showing increases in (a) temperature and (b) relative humidity from the last 10 minutes (color scale) of convection cells $\mathbf{A}$ at $\mathrm{z}=1460 \mathrm{~m}$. The contours show updrafts at $\mathrm{z}=1460 \mathrm{~m}$. Thin contours show regions with updraft intensities of $0.03 \mathrm{~m} \mathrm{~s}^{-1}$ and $0.06 \mathrm{~m} \mathrm{~s}^{-1}$, and thick contours show those with an intensity of $1 \mathrm{~m} \mathrm{~s}^{-1}$. The thick westward-pointing arrows indicate the updraft regions of low-level waves that propagated from the east. The thick solid arrow indicates the updraft region that generated convection cells $\mathbf{A}$, and the thin eastward-pointing arrow indicates the propagation of updrafts produced by the large-scale convergence. Red broken lines in (a) and (b) indicate the positions of the diagrams shown in (c) and (d). Horizontal distributions of temperature deviations from the 30-minute average (contours) and updrafts (color shading) at $\mathrm{z}=1460 \mathrm{~m}$ at (c) 1610 UTC and (d) 1700 UTC. The values on the contours show the temperature deviation values multiplied by 100 . Solid red and blue lines depict minimum and maximum temperature phases. The large open arrows in (c) and (d) show the propagation direction of the low-level waves. the east. These changes produced favorable conditions for triggering the convection cells. YS92, Oouchi (1999), and Lac et al. (2002) also reported the generation of new convection cells under similar favorable conditions. Although some updrafts were propagated from the east before 1910 UTC, no convection cells were generated at the generation point before that time. This result suggests that the timing of the generation was influenced by the more favorable atmospheric conditions caused by the large-scale convergence (Fig. 5). To investigate whether a cold pool existed in the area (Fig. 3d) before the generation of convection cells $\mathbf{A}$, the temperature distribution at $20 \mathrm{~m}$ height is shown in Fig. $4 \mathrm{~b}$. No cold pool existed around the generation point of convection cells $\mathbf{A}$ before 1910 UTC. Therefore, a cold pool did not generate the convection cells.

Figure 8a is a time-height diagram of updrafts and temperature deviations from the average along the solid white line shown in Fig. 4a (1500 to 1900 UTC). At this point on the northern side of Java Island, below $2 \mathrm{~km}$ height the temperature decreased with time as a result of the convergence of the northwesterly (I) and westerly (II) airflows (Fig. 4a). Five updrafts, each lasting about 20 minutes, occurred in succession over the 3 hours from 1500 UTC to 1800 UTC. During this period, the updrafts extended vertically from $2 \mathrm{~km}$ at 1500 UTC to $5 \mathrm{~km}$ by 1800 UTC. This variation in updraft height might be due to the large-scale convergence.

The time series of temperature variations and updraft intensity (Fig. 8b) shows that temperature decreases are associated with updrafts, and that temperature reaches a minimum at 10 minutes after each updraft peak. This 10-minute

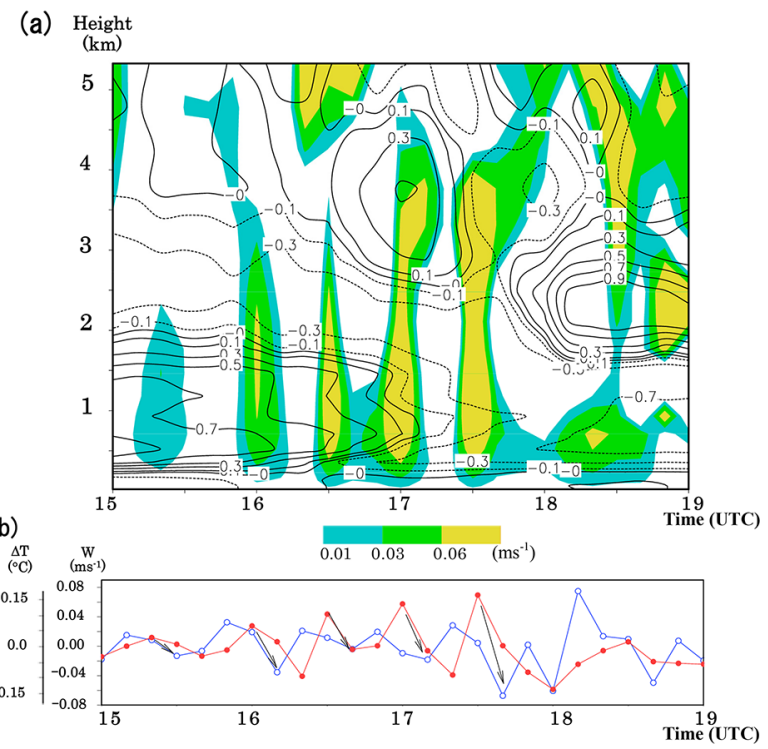

Fig. 8 (a) Height-time diagram of updrafts (color scale) and temperature deviations from the temporal average (contours) along the white line in Fig. 4a. (b) Time variations of vertical velocity (red line) and temperature deviations from the 30-minute average (blue line) at $1460 \mathrm{~m}$ height. Arrows in (b) show the phase relationship between updraft intensity and temperature. 
lag in each 36-minute cycle indicates a phase relationship of $100^{\circ}$ and suggests that the updrafts were probably not induced by moist convection, because phase of updrafts should coincide with that of temperature if updrafts were caused by convections. The time interval of the outputs of $1 \mathrm{~km}-\mathrm{NHM}$ (10 minutes), however, is too coarse to resolve the phase relationship, so we also examined the horizontal distributions of the updrafts and the temperature deviations from the 30 minute average, which was obtained by removing the influence of the large-scale convergence, at 1610 UTC and 1700 UTC (Fig. 7c and 7d). The area was south of the generation point of convection cells A (Fig. 3d). At 1610 UTC, a few bands of updrafts extending from southeast to northwest were propagating westward. This distribution of updrafts is similar to that reproduced by the $5 \mathrm{~km}-\mathrm{NHM}$ at 1500 UTC (Fig. 6), because the distribution at 1500 UTC was reflected in the initial condition of the $1 \mathrm{~km}-\mathrm{NHM}$. Temperature fluctuations were also associated with these bands of updrafts; maximum temperatures occurred along the front edge, and minimum temperatures along the rear edge of each band, a distribution that indicates a phase lag between temperature and updraft of about $90^{\circ}$. At $1700 \mathrm{UTC}$, the phase relationship between updrafts and temperature is more complicated, but its basic features are the same, that is, maximum temperatures are seen in front of the updraft regions, and minimum temperature are behind. This phase relationship suggests that the low-level waves have the structure of GWs, because the phase relationship is similar to that shown in Fig. 2.

\subsection{Convection cells $B$, generated at the edge of a weak cold pool}

From 1920 to $2010 \mathrm{UTC}$, the $27.2^{\circ} \mathrm{C}$ contour on the southern side of the convective band moved eastward (indicated by red arrows in Figs. $3 \mathrm{~d}$ and $3 \mathrm{e}$ ). As mentioned in section 4 , this contour marks the edge of a cold pool that was produced by a rainfall region that developed over Sumatra Island. The drop in temperature in the cold pool is only $0.2-0.4^{\circ} \mathrm{C}$. Despite the weakness of this cold pool, however, convection cells $\mathbf{B}$ were generated at its leading edge.

Figure 9 shows zonal-time diagrams of updrafts and temperature deviations across convection cells B. These diagrams are similar to those of convection cells A (Fig. 4), except that they show the updrafts at lower heights $(520 \mathrm{~m}$ and $130 \mathrm{~m}$ ). At $20 \mathrm{~m}$ height, the region with a large horizontal temperature gradient moving eastward (thin arrow in Fig. $9 \mathrm{~b}$ ) is the leading edge of the cold pool. A weak updraft of about $0.03 \mathrm{~m} \mathrm{~s}^{-1}$ was produced at the leading edge (contours in Fig. 9b). At $520 \mathrm{~m}$ height, the temperature is decreased along this leading edge, compared with surrounding temperatures at the same height (Fig. 9a). Because no largescale convergence occurred around convection cells $\mathbf{B}$, the updraft region is narrower, and the updraft intensity is weaker compared with convection cells A (compare Figs. 4a and 9a). At the generation point of convection cells $\mathbf{B}$, the atmosphere at $900 \mathrm{hPa}$ was already humid before the convection cells were generated (Fig. 5); the convective inhibition reached 1.1 $\mathrm{J} \mathrm{kg}^{-1}$ at $1800 \mathrm{UTC}$, about 2 hours before convection cells B were generated.
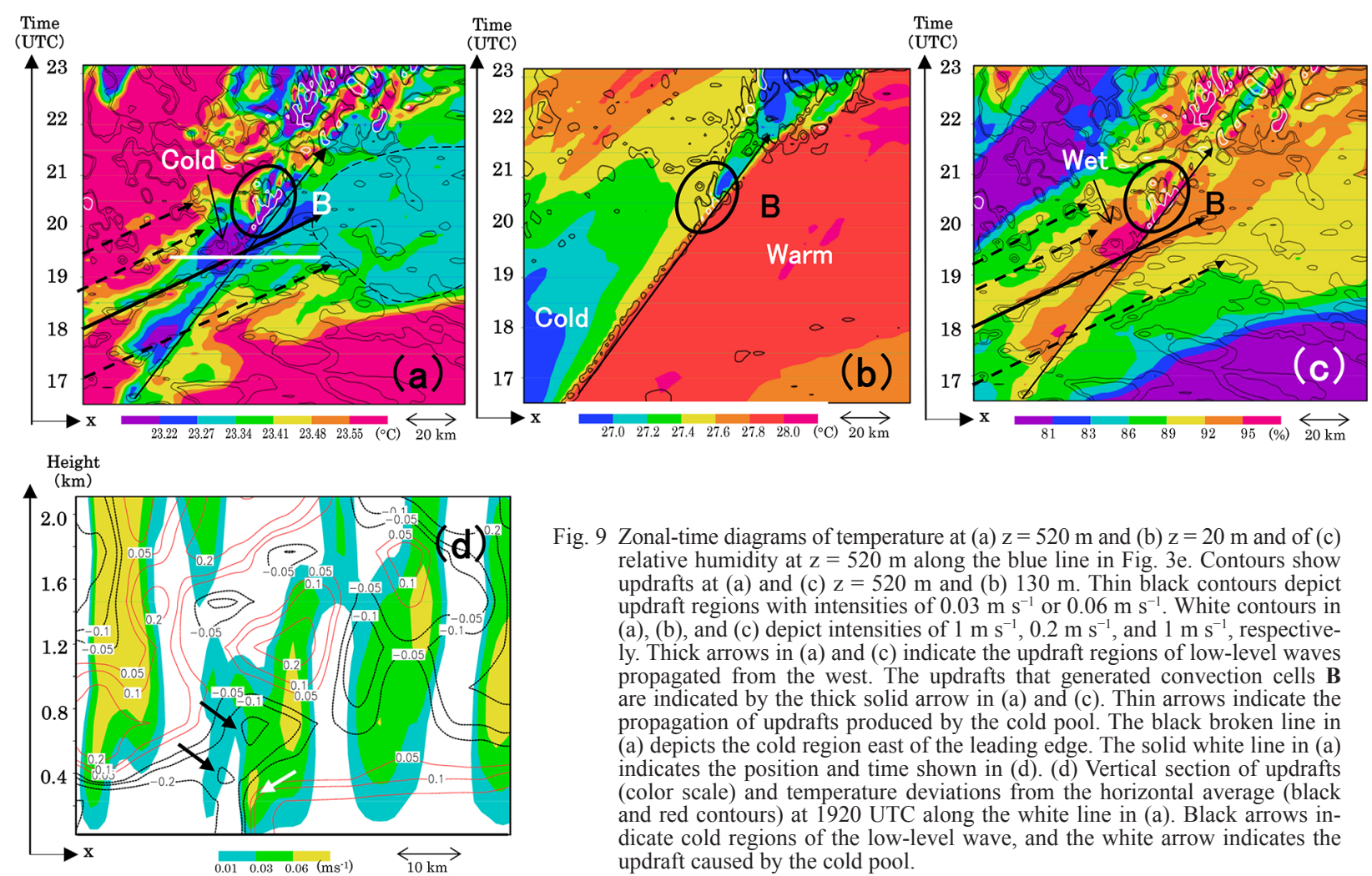

Fig. 9 Zonal-time diagrams of temperature at (a) $z=520 \mathrm{~m}$ and (b) $\mathrm{z}=20 \mathrm{~m}$ and of (c) relative humidity at $\mathrm{z}=520 \mathrm{~m}$ along the blue line in Fig. 3e. Contours show updrafts at (a) and (c) $\mathrm{z}=520 \mathrm{~m}$ and (b) $130 \mathrm{~m}$. Thin black contours depict updraft regions with intensities of $0.03 \mathrm{~m} \mathrm{~s}^{-1}$ or $0.06 \mathrm{~m} \mathrm{~s}^{-1}$. White contours in (a), (b), and (c) depict intensities of $1 \mathrm{~m} \mathrm{~s}^{-1}, 0.2 \mathrm{~m} \mathrm{~s}^{-1}$, and $1 \mathrm{~m} \mathrm{~s}^{-1}$, respectively. Thick arrows in (a) and (c) indicate the updraft regions of low-level waves propagated from the west. The updrafts that generated convection cells B are indicated by the thick solid arrow in (a) and (c). Thin arrows indicate the propagation of updrafts produced by the cold pool. The black broken line in (a) depicts the cold region east of the leading edge. The solid white line in (a) indicates the position and time shown in (d). (d) Vertical section of updrafts (color scale) and temperature deviations from the horizontal average (black and red contours) at 1920 UTC along the white line in (a). Black arrows indicate cold regions of the low-level wave, and the white arrow indicates the updraft caused by the cold pool. 
Above the cold pool, other updrafts propagated from the west (thick solid and broken line arrows in Figs. 9a and 9c) at $8.3 \mathrm{~m} \mathrm{~s}^{-1}$; this is much faster than the propagation speed of the leading edge of the cold pool. We deduced that these updrafts were propagating from convection cells over Sumatra Island but could not trace them back to their origin. Figures $10 \mathrm{a}$ and $10 \mathrm{~b}$ show 10-minute changes of temperature and relative humidity at a height of $520 \mathrm{~m}$. The updraft regions propagated from the west coincide well with regions with decreased temperatures. This relationship between updrafts and temperature, which is the same as that observed for convection cells $\mathbf{A}$, indicates that these updrafts of low-level waves have the structure of GWs.

When GWs propagating from the west reached the leading edge of the cold pool, the temperature decreased (Fig. 9a) and the relative humidity increased (Fig. 9c), and convection cells $\mathbf{B}$ were generated in this cold, humid region. These conditions at the generation point are the same as those that prevailed at the generation point of convection cells $\mathbf{A}$, but a longer time was needed to generate convection cells $\mathbf{B}$. Because there was no large-scale convergence at the generation point of convection cells $\mathbf{B}$, the temperature decrease there was much smaller than that at the generation point of convection cells $\mathbf{A}$ and the updrafts were weaker; as a result, the generation of convection cells $\mathbf{B}$ took a longer time.

Figure $9 \mathrm{~d}$ shows the vertical distribution of the updrafts and temperature deviations from the horizontal average along the white line shown in Fig. 9a at 1920 UTC, 50 minutes before convection cells B were generated. Regions colder than $-0.2{ }^{\circ} \mathrm{C}$ (black arrows) on the western side of the updrafts (behind the propagating low-level waves) were above the updrafts of the cold pool (white arrow). By comparing
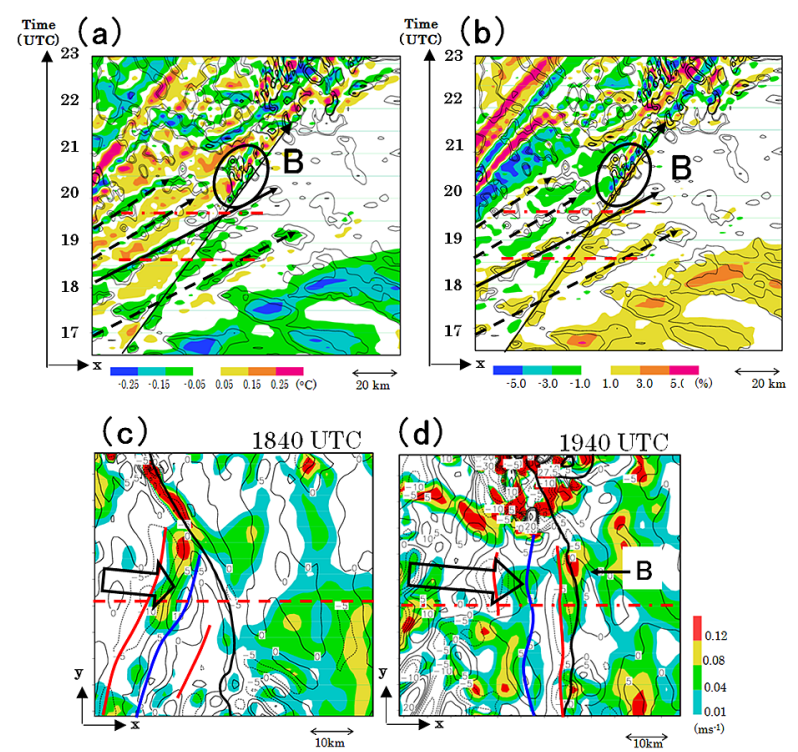

Fig. 10 Same as Fig. 7, except that (a) and (b) convective cells $\mathbf{B}$ at $\mathrm{z}=520 \mathrm{~m}$, and (c) and (d) are for convective cells B at $z=520 \mathrm{~m}$ : (c) 1840 UTC; (d) 1940 UTC. The thick black line in (c) and (d) indicates the leading edge of the cold pool. this distribution with that modeled by YS92 (Fig. 2), we deduced that the same mechanism as that inferred by YS92 generated convection cells $\mathbf{B}$, though at a lower height.

Besides the cold pool and low-level waves, the temperature east of the leading edge of the cold pool might have influenced the generation of convection cells B. That is, warm region at $520 \mathrm{~m}$ height east of the leading edge moved northeastward, with the result that the temperature there became cooler at 1800 UTC (indicated by thin broken line in Fig. 9a). These warm and cold regions roughly correspond to northwesterly (I) and westerly (II) airflows, respectively (airflows (I)-(III) are shown in Fig. 3). Thus, the temperature at $520 \mathrm{~m}$ height east of convection cells $\mathbf{B}$ was altered by the land and sea breeze circulation around Java Island (this change indicates the modification of temperature due to the land and sea breeze in airflow (II), as mentioned in section 4). However, the temperature decreases due to the presence of the cold pool and the propagation of low-level waves were probably more effective in generating convection cells $\mathbf{B}$ than the decrease due to the land and sea breeze circulation because the temperature above the cold pool's leading edge after the passage of the updrafts was lower than the temperature east of the leading edge.

Though another low-level wave propagated over the leading edge of the cold pool at 1740 UTC, before the generation of convection cells $\mathbf{B}$, no convection cells were generated at that time. To identify the updraft that had the largest impact on the generation of convection cells $\mathbf{B}$, we compared the intensity of updrafts with temperature and relative humidity before the passage of the cold pool's leading edge. The intensity of the updraft that generated convection cells B (thick solid arrow in Figs. 9a, c and 10a, b) exceeded $0.03 \mathrm{~m} \mathrm{~s}^{-1}$ for a longer time compared with the other updrafts. The temperature remained colder than $23.41^{\circ} \mathrm{C}$ for a longer time (Fig. 9a), and the region in which the relative humidity was greater than $95 \%$ also expanded (Fig. 9c). The change in temperature, however, was the most significant (Fig. 10a), though the change in relative humidity was small (Fig. 10b) because the atmosphere was already almost saturated (Fig. $5 b)$. We inferred that these differences explain why convection cells $\mathbf{B}$ were generated after the passage of the second updraft.

We examined the horizontal distributions of temperature and updrafts near the generation point at 1840 UTC and 1940 UTC (Figs. 10c and 10d) to determine the phase relationship between temperature and updrafts before the generation of convection cells B. A few bands of updrafts extend southwestward or southward above the cold pool. These updraft bands are propagating from the west, and maximum and minimum temperatures are just in front of and just behind, respectively, the updraft bands, the same as with convection cells $\mathbf{A}$. This phase relationship also suggests that the low-level waves that generated convection cells $\mathbf{B}$ had the structure of GWs. 


\section{Summary}

We used a high-resolution 3-dimensional non-hydrostatic model to investigate the generation and development processes of convection cells in tropical regions. The results are summarized below:

(1) Convection cells A: Large-scale convergence caused by sea and land breezes cooled the lower atmosphere and increased the relative humidity in a region $20-40 \mathrm{~km}$ wide, thus producing favorable conditions for the generation of convection cells ((i), Fig. 11 (a)).

(2) Convection cells B: The atmosphere just above a weak cold pool was almost saturated, a condition favorable for the generation of convection cells. The weak cold pool produced a weak updraft along its leading edge ((ii), Fig. 11b).

(3) When updrafts of low-level waves encountered weak updrafts, such as those caused by the large-scale convergence (convection cells A) or the weak cold pool (convection cells B), convection cells were generated ((iii), Figs. 11a and 11b).

(4) Updrafts of low-level waves below a height of a few kilometers made the lower atmosphere cooler and moister, triggering the generation of new convection cells. These results are consistent with those of YS92, Oouchi (1999), and Lac et al. (2002) ((iv), Figs. 11a and 11b). The changes due to the low-level waves were smaller than those due to the large-scale convergence. Therefore, low-level waves play only a supplemental role in the generation of convection cells, but they directly determine the timing of their generation.

(5) In this study, the point at which the convection cells were generated and the timing of their generation were directly determined by low-level waves. The intensity
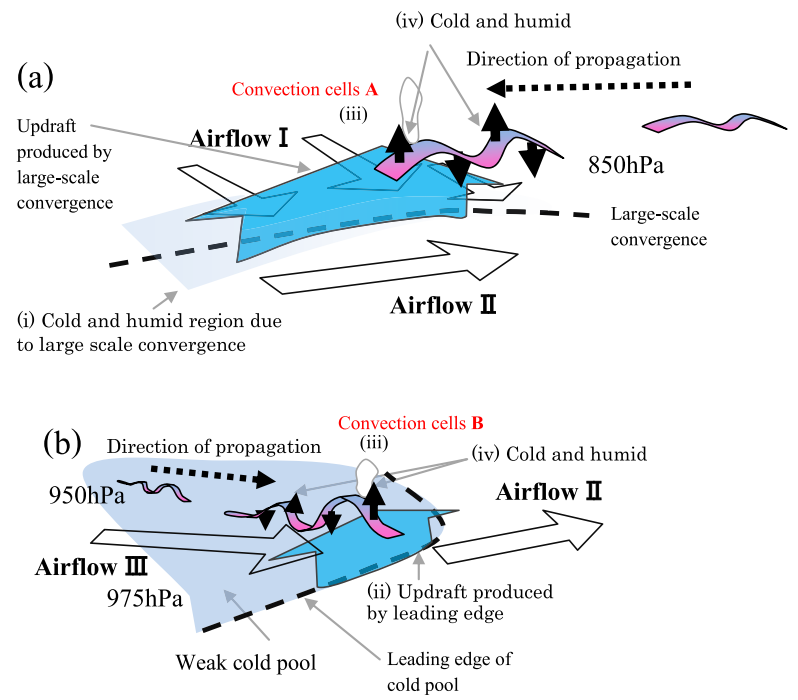

Fig. 11 Schematic illustrations of the generation of (a) convection cells A and (b) convection cells $\mathbf{B}$. of the low-level waves might be one factor that determines whether the waves can generate convection cells. The large-scale convergence, which created favorable conditions in the lower atmosphere for the generation of convection cells, determined the timing at which convection cells could be generated easily. These features are common in convection cells $\mathbf{A}$ and $\mathbf{B}$.

(6) The phase structure of the low-level waves was similar to that of the GWs, as shown by 2-dimensional models.

Reproduction of the processes generating convection cells from realistic initial conditions with fine-resolution numerical models can provide useful information for mitigating damage caused by severe weather events in tropical regions.

Analyses of heavy rainfalls occurring at mid-latitudes have shown that the presence of cold, dry air at middle height $(3-5 \mathrm{~km})$ is important for the development of intense convection (e.g., Seko et al., 1999). However, in this study, the height at which conditions affected the generation and development of convection cells was lower $(0.5-2 \mathrm{~km})$. The effective height for the development of convection cells might depend on the stage of development and the particular geographical region where the convection cells are being generated.

For convection cells $\mathbf{A}$, the magnitude of the updrafts of low-level waves was $0.06-0.09 \mathrm{~m} \mathrm{~s}^{-1}$ (Figs. 7c and 7d) and the period of the updrafts was about $30 \mathrm{~min}$ (Fig. 8). As a result, the almost-saturated air (Fig. 5) was lifted 108-162 m in the updraft regions of low-level waves. In this study, these small displacements accompanied by changes in temperature and relative humidity $\left(-0.25^{\circ} \mathrm{C}\right.$ and $\left.+3-4 \%\right)$ (Figs. $7 \mathrm{a}$ and $7 \mathrm{~b})$ triggered the generation of convection cells. Whether small displacements such as those shown in this study can trigger convection cells in the actual atmosphere should be investigated using observation data.

Little observational evidence for the generation of individual convection cells by GWs in tropical regions has been reported to date. However, advanced observation systems consisting of meteorological satellites and Doppler lidars have recently been developed. Meteorological satellites can now observe cloud initiations by rapid scan observations at time intervals of about $5 \mathrm{~min}$, and Doppler lidar-equipped ocean-going vessels can observe airflows proceeding the generation of convection cells.

Numerical modeling studies have been carried out to gain knowledge for mitigating damage caused by severe weather events in tropical regions. For instance, Kyoto University and the Meteorological Research Institute carried out a project titled "International Research for Prevention and Mitigation of Meteorological Disasters in Southeast Asia" in collaboration with institutions in Southeast Asia (Saito et al., 2011). The number of numerical modeling studies of convection cells in tropical regions is expected to increase in the future. 
If mechanisms essential for the generation or maintenance of convection cells are identified before observations are made, the observations can be performed more effectively because the observation can be focused on these mechanisms. Comprehensive studies including both observations and numerical simulations of convection cells are a promising future approach. We expect the results of this study to provide useful information for designing and carrying out such observational and numerical simulation studies of the generation of convection cells in tropical regions.

\section{Acknowledgments}

The authors express their gratitude to Dr. Masanori Yamasaki, Dr. Kazuyoshi Oouchi, and Dr. Hiroyuki Yamada of JAMSTEC and to two anonymous reviewers for valuable comments and information. This work was conducted as part of the project "International research for prevention and mitigation of meteorological disasters in Southeast Asia," directed by Professor Shigeo Yoden of Kyoto University, with the support of special coordination funds for promoting science and technology during fiscal years 2007 to 2009 from the Ministry of Education, Culture, Sports, Science and Technology of Japan.

\section{References}

Fujita, M., F. Kimura and M. Yoshizaki, 2009: Morning precipitation peak over the strait of Malacca under a calm condition. Mon. Wea. Rev., 138, 1474-1486.

Kain, J. and J. Fritsch, 1993: Convective parameterization for mesoscale models: The Kain-Fritsch scheme, the representation of cumulus convection in numerical models. Meteor. Monogr., 24, 165-170.

Lac, C., J-P. Lafore and J-L. Redelsperger, 2002: Role of gravity waves in triggering deep convection during TOGA COARE. $J$. Atmos. Sci., 59, 1293-1316.

Lane, T. P. and F. Zhang, 2011: Coupling between gravity wave and tropical convections at mesoscales. J. Atmos. Sci., 68, 25822598.

Moteki, Q., R. Shirooka, H. Kubota, T. Ushiyama, K. K. Reddy, K. Yoneyama, M. Katsumata, N. Sato, K. Yasunaga, H. Yamada, B. Geng, M. Fujita, M. Yoshizaki, H. Ueda and T. Chuda, 2008: Mechanism of the northward propagation of mesoscale convec- tive systems observed on 15 June 2005 during PALAU2005. $J$. Geophys. Res., 113, D14126, doi:10.1029/2008JD009793.

Nicholls, M. E., R. A. Pielke and W. R. Cotton, 1991: Thermally forced gravity waves in an atmosphere at rest. J. Atmos. Sci., 48, 1869-1884.

Onogi, K., J. Tsutsui, H. Koide, M. Sakamoto, S. Kobayashi, H. Hatsushika, T. Matsumoto, N. Yamazaki, H. Kamahori, K. Takahashi, S. Kadokura, K. Wada, K. Kato, R. Oyama, T. Ose, N. Mannoji and R. Taira, 2007: The JRA-25 Reanalysis. J. Meteor. Soc. Japan, 85, 369-432.

Oouchi, K., 1999: Hierarchical organization of super cloud cluster caused by WISHE, Convectively induced gravity waves and cold pool. J. Meteor. Soc. Japan, 77, 907-927.

Saito, K., T. Fujita, Y. Yamada, J. Ishida, Y. Kumagai, K. Aranami, S. Ohmori, R. Nagasawa, S. Kumagai, C. Muroi, T. Kato, H. Eito and Y. Yamazaki, 2006: The operational JMA Nonhydrostatic Mesoscale Model. Mon. Wea. Rev., 134, 1266-1298.

Saito, K., T. Kuroda, S. Hayashi, H. Seko, M. Kunii, Y. Shoji, M. Ueno, T. Kawabata, S. Yoden, S. Otsuka, N. J. Trilaksono, T. Y. Koh, S. Koseki, L. Duc, X. K. Xin, W. K. Wong and K. C. Gouda, 2011: International Research for Prevention and Mitigation of Meteorological Disasters in Southeast Asia. Tech. Rep. MRI, 65, 198 pp.

Seko, H., T. Kato, K. Saito, M. Yoshizaki, K. Kusunoki and M. Maki, 1999: Analytical and numerical studies of a quasi-stationary precipitation band observed over the Kanto area associated with Typhoon 9426 (Orchid). J. of Meteor. Soc. Japan, 77, 929-948.

Wang, C.-C., G. Tai-Jen and S-Y. Huang, 2011: Remote trigger of deep convection by cold outflow over the Taiwan Strait in the Mei-Yu season: A modeling study of the 8 June 2007 case. Mon. Wea. Rev., 139, 2854-2874.

Wu, P., M. Hara, H. Fudeyasu, M. D. Yamanaka, J. Matsumoto, F. Syamsudin, R. Sulistyowati and Y. S. Djajadihardja, 2007: The impact of trans-equatorial monsoon flow on the formation of repeated torrential rains over Java island. SOLA, 3, 93-96.

Yamasaki, M., 1983: A further study of the tropical cyclone without parameterizing the effect of cumulus convection, 1983. Papers in Meteorology and Geophysics, 34, 221-260.

Yamasaki, M., 1984: Dynamics of convective clouds and 'CISK' in vertical shear flow with its application to easterly waves and squall line systems. J. Meteor. Soc. Japan, 62, 833-863.

Yamasaki, M. and H. Seko, 1992: The effect of gravity waves on convection cells, Proceedings of the Spring Meeting of the Meteorological Society of Japan, A108 (in Japanese). 


\title{
雨季におけるスマトラ島付近の対流セルの発生メカニズム
}

\author{
瀬古＼cjkstart弘、林 修吾、斉藤和雄（気象研究所予報研究部）
}

熱帯域の対流セルの発生メカニズムを、高解像度 3 次元非静力学モデルを用いて調べた。気象庁気候データ同化システムの 再解析值を初期值・境界值に用い、格子間隔 $1 \mathrm{~km}$ のダウンスケール実験を行って、スマトラ島付近の対流セルを再現すると、 対流セルは、下層の波の上昇流域が大きなスケールの収束域や弱い冷気塊の先端を通過するときに発生していた。大きなスケー

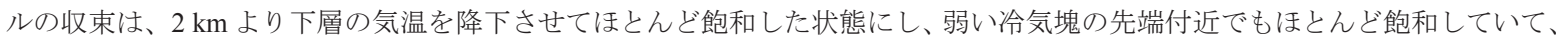
ともに対流発生に好都合な環境であった。下層の波の上昇流は、さらに気温を降下させて、湿度を増加させ、そこで新しい対 流セルを発生させていた。この下層の波は、上昇流と気温の位相差が約90度であり、重力波の構造を持っていた。大規模な収 束が対流の発生しやすい期間を決定し、下層の波の強さが対流の発生のタイミングを決定していた。 